\title{
CHEMICAL COMPOSITION AND BIOLOGICAL ACTIVITIES OF THE ESSENTIAL OILS AND THE METHANOLIC EXTRACTS OF BUNIUM INCRASSATUM AND BUNIUM ALPINUM FROM ALGERIA
}

\author{
EL KOLLI HAYET ${ }^{1}{ }^{*}$, LAOUER HOCINE $^{2}$ AND EL KOLLI MERIEM ${ }^{2}$ \\ 1 : Laboratoire des matériaux polymériques multiphasiques, Département de Génie des procédés, Faculté de technologie, \\ Université Ferhat Abbes, Sétif 19000, Algeria. \\ $2:$ Laboratoire de valorisation des ressources naturelles biologiques, Faculté de la nature et de la vie, \\ Université Ferhat Abbes, Sétif 19000, Algeria
}

\begin{abstract}
In order to study the curing proprieties of endemic Algerian plants, it is evaluated the chemical composition and four biological activities of two Apiaceae species, which are Bunium incrassatum and Bunium alpinum. The essential oils (EO) obtained by hydro-distillation of dried aerial parts were analyzed by GC/ MS. The antibacterial activity was investigated using the disc diffusion assay against ten (10) Gram-positive and Gram-negative bacteria. Antioxidant activity was evaluated by DPPH technique. Methanolic extracts (Me EXTs) were used in studying in vitro anti-inflammatory activity using egg albumin technique and in vitro anti-hemolytic activity using HBRC technique. The EO yield based on dried plant material was $0.09 \%$ for $B$. incrassatum and $0.10 \%$ for $B$. alpinum. Thirtyone compounds (corresponding to $97.19 \%$ ) were identified for $B$. incrassatum. The main component was palmitic acid (18.39\%). While twenty-four compounds (coresponding $87.33 \%$ ) were identified for B. alpinum. The main component was caryophyllene oxide (33.84\%). The study of antibacterial activity demonstrated that the EOs showed a modest antibacterial activity compared to gentamicin. The antioxidant activity revealed that EOs and Me EXTs demonstrated a very important anti-radical activity compared to standards (BHT, BHA, tocopherol, quercitin and rutin). The Me EXTs demonstrated also, significant antihemolytic and anti-inflammatory activities to those of standard (sodium diclofenac). It was found that all these activities are much related to the chemical composition of EO and Met EXTs. These activities could be exploited in the food industry for food preservation or in pharmaceutical industry.
\end{abstract}

Keywords : Bunium, anti-oxidant activity, anti-inflammatory activity, anti-hemolytic activity, antibacterial activity, essential oil.

\section{INTRODUCTION}

The increased use of drugs with over prescribing has led to the development of resistance to drugs especially antibiotics. Therefore, there is growing interest in the development of new types of natural effective and non toxic compounds "Research of effective plants agents". Herbal and botanical products, such EOs and plant extracts, have been studied for their biological activities. EOs have several activities; other than antibacterial and antiviral effects, most of them possess insecticidal, antifungal, acaricidal, cytotoxic and antioxidant properties ${ }^{1}$. Therefore, they are intensely investigated in the fields of pharmacology, pharmaceutical botany, medical and clinical microbiology, phytopathology and food preservation.

Bunium genus possesses a range of compounds with many biological activities. It comprises more than 50 species ${ }^{2}$ are distributed in Africa ${ }^{3,4}$, in Europe $^{5}$ and in Asia ${ }^{6-8}$. Bunium species are used as additives in foods for their carminative, anti-dyspepsia and anti-spasmodic effects ${ }^{9}$. B. persicum is used as carminative, anti-obesity and lactogage ${ }^{10}$, the roots of $B$. paucifolium are eaten like potatoes in eastern Anatolia ${ }^{11}$ also that, its rhizomes are used in treatment of urinary inflammation ${ }^{12}$.

Since the plant-derived became a source of novel therapeutics and in order to exploit local species, we aimed to study the biological activities of the essential oils (EOs) and methanolic extracts (Me EXT) of Bunium alpinum and Bunnium incrassatum knowing that the two species were never studied before.

\section{MATERIAL AND METHODS}

\subsection{Chemical composition of essential oils}

\section{Plant Material}

Flowering aerial parts of $B$. incrassatum were collected in Timellouka region (West Setif, Algeria) during Mai-July (2010-2014). However, flowering aerial parts of B. alpinum were collected at Megress Mountain (North Setif, Algeria) during the same period. The harvested plants material was air-dried in a shaded area at ambient temperature.

Extraction of Volatiles

EOs were obtained by hydro-distillation in a Clevenger-type apparatus ${ }^{13}$ Each isolated oil was stored in refrigerator at a steady Temperature of $4{ }^{\circ} \mathrm{C}$ until use.

Essential Oil Analysis by Gas Chromatography-Mass Spectrometry

GC and GC-MS analysis were carried out using an Agilent 6890N gas chromatograph apparatus equipped with a flame ionization detector (FID) and coupled to a quadrupole Agilent 5973 network mass selective detector working in electron impact (EI) mode at $70 \mathrm{eV}$. The gas chromatograph was equipped with two fused silica capillary columns HP-1. The analytical parameters were the following: the carrier gas was helium at a flow rate of $1 \mathrm{ml} / \mathrm{min}$. The oven temperature was programmed from 60 to $250{ }^{\circ} \mathrm{C}$ at $2{ }^{\circ} \mathrm{C} / \mathrm{min}$ and held isothermal for $40 \mathrm{~min}$. The injector (split mode, ratio 1/100) temperature was $250{ }^{\circ} \mathrm{C}$. The FID temperature was set at $250^{\circ} \mathrm{C}$, and in the GC-MS analyses, the temperatures of the ion source and transfer line were 170 and $280^{\circ} \mathrm{C}$, respectively. The constituents of the essential oil were identified by comparison of their mass spectral pattern and retention indices (RI) with those of pure compounds registered in literature data and with a laboratory-made database built from authentic compounds ${ }^{14}$.

\subsection{Preparation of methanolic extracts}

Methanolic extracts (Me EXTs) were obtained using Athamena method (15). The aerial parts of $B$. alpinum and $B$. incrassatum were separately pulverized into fine powder. Then $20 \mathrm{~g}$ of each were macerated in $100 \mathrm{ml}$ wateralcohol mixture at a ratio of $1 / 10(\mathrm{v} / \mathrm{v})$. Then the mixtures were swirled for 72 hours at ambient temperature. After that, these mixtures were individually filtered through filter paper and the entire extraction process was repeated (three times) on the residue obtained from the filtration process. The filtrates were individually pooled and methanol was removed from the filtrates under reduced pressure (Rotavapor). Finally; Me EXTs were cooled in a desiccator before the yield of each extract was calculated.

\subsection{Total phenolic content (TPC)}

The TPC was obtained using the Folin-Ciocalteu reagent method ${ }^{16}$ A volume of $200 \mu \mathrm{l}$ of each Me EXT was added to $1 \mathrm{ml}$ of Folin-Ciocalteu reagent dissolved in water at a ratio of $1 / 10(\mathrm{v} / \mathrm{v})$. Solutions were mixed and incubated at room temperature. After $4 \mathrm{~min}, 800 \mu \mathrm{l}$ of sodium carbonate $(75$ $\mathrm{mg} / \mathrm{ml}$ ) were added. The final mixture was shaken thoroughly and incubated for 2 hours in obscurity at room temperature.

Absorbance was measured at $765 \mathrm{~nm}$ using a UV/vis spectrophotometer. Triplicate measurements were made for each sample. A calibration curve of Gallic acid (GA) ranging from $0-250 \mu \mathrm{g} / \mathrm{ml}$ was prepared separately. Results were determined by the regression equation of the calibration curve and were expressed as milligram GA equivalents (GAE) per gram dry weight of draw material (DW).

\subsection{Antibacterial activity of essential oils}

Bacterial strains

Reference strains of all the bacteria were obtained from the collection of the American Culture Collection Type (ATCC) are presented in table 1. 
Table1. Strains of bacteria.

\begin{tabular}{|c|c|c|c|}
\hline Bacteria & Gram & Origin & Code \\
\hline $\begin{array}{c}\text { Pseudomonas } \\
\text { aeruginosa }\end{array}$ & - & ATCC & 27853 \\
\hline Escherichia coli & - & ATCC & 25922 \\
\hline Salmonella typhimurium & - & ATCC & 13311 \\
\hline Citrobacter freundii & - & ATCC & 8090 \\
\hline Klebsiella pneumonia & - & ATCC & 700603 \\
\hline Proteus mirabilis & - & ATCC & 35659 \\
\hline Bacillus cereus & + & ATCC & 10876 \\
\hline Enterococcus faecalis & + & ATCC & 49452 \\
\hline Lysteria monocytogenes & + & ATCC & 15313 \\
\hline Staphylococcus aureus & + & ATCC & 25923 \\
\hline
\end{tabular}

\section{Disc diffusion assay}

Diffusion method was carried out according to Bauer method ${ }^{17}$. Briefly, a culture suspension of the tested bacteria $\left(10^{6} \mathrm{CFU} / \mathrm{ml}\right)$ was spread on the solid media plates (Muller Hinton; MH). 6 mm's paper discs were impregnated with $10 \mu \mathrm{l}$ of serial dilutions in dimethyl-sulfoxide (DMSO) and placed onto the solid media plates $(\mathrm{MH})$. The antibacterial activity was evaluated by measuring the inhibition zones expressed in $\mathrm{mm}$ against the tested bacteria after $24 \mathrm{~h}$ of incubation at $37{ }^{\circ} \mathrm{C}$. Gentamicin $(10 \mu \mathrm{g} / \mathrm{disc})$ was used as positive control.

2.5. Anti-oxidant activity using DPPH scavenging assay

The hydrogen atom's donation ability of chemical compounds was measured on the basis to scavenge the 2,2-diphenyl-1-picrylhydrazil free radical ${ }^{18,19}$. Fifty microliter $(50 \mu \mathrm{l})$ of various concentrations of the EXT (in methanol) and EOs (in DMSO) were added to $1250 \mu$ l of DPPH solution $(0.4 \mathrm{mM}$ in methanol). After $30 \mathrm{~min}$ of incubation in the obscurity at room temperature, the absorbance was read against a blank at $517 \mathrm{~nm}$ using UV/vis spectrophotometer. DPPH free radical scavenging activity in percentage (\%) was calculated using the following formula :

DPPH scavenging activity $(\%)=\left(\mathrm{A}_{\text {blank }}-\mathrm{A}_{\text {sample }} / \mathrm{A}_{\text {blank }}\right) \times 100$

Where : $\mathrm{A}_{\text {blank }}$ is the absorbance of the control reaction (containing all reagents except the test compound), $\mathrm{A}_{\text {ample }}$ is the absorbance of the test compound. Extract concentration providing 50\% inhibition (IC50) was calculated from the graph plotted of inhibition percentage against extract concentrations. Synthetics; BHT, BHA, tocopherol, quecitine and rutine were used as positive controls.

2.6. Evaluation of In vitro anti-inflammatory activity

Anti-inflammatory activity of Me EXTs was evaluated by protein denaturation method ${ }^{20,21}$. Diclofenac sodium, a powerful non-steroidal antiinflammatory drug was used as a standard. The reaction mixture consisting of $2 \mathrm{ml}$ of different concentrations of Me EXT $(100-500 \mu \mathrm{g} / \mathrm{ml})$ or standard diclofenac sodium $(100$ and $200 \mu \mathrm{g} / \mathrm{ml})$ and $2.8 \mathrm{ml}$ of phosphate buffered saline ( $\mathrm{pH}$ 6.4) was mixed with $2 \mathrm{ml}$ of egg albumin (from fresh hen's egg) and incubated at $(27 \pm 1){ }^{\circ} \mathrm{C}$ for $15 \mathrm{~min}$. Denaturation was induced by keeping the reaction mixture at $70{ }^{\circ} \mathrm{C}$ in water bath for $10 \mathrm{~min}$. After cooling, the absorbance was measured at $660 \mathrm{~nm}$ using double distillated water as blank. Each experiment was done in triplicate and the average was taken. The percentage inhibition of protein denaturation was calculated using the following formula: \% Inhibition $=\left(\mathbf{A}_{t}-\mathbf{A}_{c}\right) / \mathbf{A}_{c} \times 100$, Where: $\mathrm{A}_{t}$ is the absorbance of test sample; $\mathrm{A}$ is the absorbance of control.

2.7. Evaluation of in vitro anti-hemolytic activity using HRBC method

\section{Preparation of Human Red Blood Cells (HRBC) Suspension}

Fresh whole human blood was collected and mixed with equal volume of sterilized Alsever solution ( $2 \%$ dextrose, $0.8 \%$ sodium citrate, $0.05 \%$ citric acid and $0.42 \%$ sodium chloride in water). The blood was centrifuged at 3000 $\mathrm{rpm}$ for $10 \mathrm{~min}$ and packed cells were washed three times with isosaline $(0.85$ $\%, \mathrm{pH}$ 7.2). The volume of the blood was measured and reconstituted as a percentage $\%(\mathrm{v} / \mathrm{v})$ suspension with isosaline ${ }^{22}$.

\section{Heat Induced Hemolysis}

The principle involved here is the stabilization of human red blood cell membrane by hypotonicity induced membrane lysis. The mixture contains 1 $\mathrm{ml}$ phosphate buffer ( $\mathrm{pH} 7.4,0.15 \mathrm{M}), 2 \mathrm{ml}$ hyposaline $(0.36 \%), 0.5 \mathrm{ml} \mathrm{HRBC}$ suspension $(10 \% \mathrm{v} / \mathrm{v})$ with $0.5 \mathrm{ml}$ of Me EXT. This mixture, the standard drug diclofenac sodium (DC) of various concentrations (50, 100, 250, 500,
1000 and $2000 \mu \mathrm{g} / \mathrm{ml}$ ) and the control (distillate water instead of hyposaline to produce $100 \%$ hemolysis) were incubated at $37^{\circ} \mathrm{C}$ for $30 \mathrm{~min}$ and centrifuged respectively. The hemoglobin content in the suspension was estimated using spectrophotometer at $560 \mathrm{~nm}^{22}$.

The percentage of hemolysis of HRBC membrane can be calculated using the formula:

$\%$ hemolysis $=\left(\mathrm{A}_{2} / \mathrm{A}_{1}\right) \times \mathbf{1 0 0}$

The percentage of HRBC membrane stabilization can be calculated using the formula:

The inhibition of hemolysis or the protection $=100 \times\left(1-A_{2} / A_{1}\right)$

Where: $A_{1}$ is the absorption of the control sample. $A_{2}$ is the absorption of test sample solution ${ }^{23}$.

\section{RESULTS AND DISCUSSION}

\subsection{Essential Oil Analysis}

EO obtained by hydrodistillation of the areal parts of $B$. incrassatum was isolated with a yield of $0.09 \%$. However, B. alpinum gave a yield of $0.1 \%$ (based on dried plant material). The isolated EOs were yellowish clear limpids with strong aromatic fragrances and showed a high solubility in methanol and dimethylsulfoxyde (DMSO). The main components represented more than 97 $\%$ of the total of $B$. incrassatum EO and more than $87 \%$ of of B. alpinum EO.

$B$ incrassatum (EO) had exhibited thirty one identified compounds (table 2) by comparison of their retention indexes and the mass spectra of each GC component with those of standards. The abundant components were: terpens and their derivatives, but, the major component was palmetic acid (18.39 $\%$ ), followed by caryophyllene oxide (17.36\%), $\beta$-eudesmol (13.95\%), n-pentacosane $(5.13 \%), 10$-epi- $\alpha$-muurolol (4.36\%), hedycaryol (4.14\%) and spatuleneol (4.04\%).

Table 2 Chemical composition of $B$. incrassatum (EO).

\begin{tabular}{|c|c|c|c|}
\hline Compound & RI & $\%$ & $\begin{array}{l}\text { Retention } \\
\text { time (min) }\end{array}$ \\
\hline thymol & 1289 & 0.65 & 18.93 \\
\hline carvacrol & 1298 & 0.76 & 19.11 \\
\hline$\beta$-elemene & 1389 & 0.28 & 22.08 \\
\hline (E)-caryophyllene & 1417 & 2.62 & 22.98 \\
\hline (E)- $\beta$-farnesene & 1440 & 0.25 & 23.48 \\
\hline$\alpha$-humulene & 1452 & 0.31 & 23.84 \\
\hline$\gamma$-muurolene & 1478 & 0.67 & 24.29 \\
\hline D-germacrene & 1484 & 0.55 & 24.5 \\
\hline$\alpha$-muurolene & 1500 & 0.27 & 24.86 \\
\hline$\beta$-bisabolene & 1505 & 0.48 & 24.94 \\
\hline$\beta$-sesquiphellandrene & 1521 & 0.65 & 25.33 \\
\hline 1-endo-bourbonanol & 1518 & 2.43 & 25.44 \\
\hline$\beta$-calacorene & 1544 & 0.66 & 26 \\
\hline Hedycaryol & 1546 & 4.14 & 26.1 \\
\hline spatuleneol & 1577 & 4.04 & 26.98 \\
\hline caryophyllene oxide & 1582 & 17.36 & 27.12 \\
\hline salvial-4(14)-en-1-one & 1594 & 2.4 & 27.3 \\
\hline carvone & 1595 & 0.71 & 27.6 \\
\hline humulene epoxide-I & 1608 & 1.85 & 27.68 \\
\hline 10-epi- $\alpha$-muurolol & 1640 & 4.36 & 28.36 \\
\hline$\beta$-eudesmol & 1649 & 13.95 & 28.67 \\
\hline apiol & 1677 & 0.94 & 28.98 \\
\hline$\alpha$-bisabolol & 1685 & 2.11 & 29.19 \\
\hline apritone & 1708 & 2.98 & 29.63 \\
\hline myristic acid & 1720 & 2.4 & 30.53 \\
\hline 6,10,14-Trimethylpentadecan-2-one & 1795 & 1.61 & 32.38 \\
\hline pentadecanoic acid & 1820 & 1.8 & 32.66 \\
\hline palmitic acid & 1984 & 18.39 & 34.87 \\
\hline linoleic acid & 2173 & 1.09 & 38.22 \\
\hline n- tricosane & 2300 & 1.35 & 41.9 \\
\hline n- pentacosane & 2500 & 5.13 & 44.15 \\
\hline
\end{tabular}


Table 3 shows the chemical composition of B. alpinum EO, twenty four compounds were identified, the most abundant one was caryophyllene oxide (II) $(33.84 \%)$, followed by humulene epoxide I $(8.37 \%)$, n-pentacosane $(6.41 \%)$, ledenoxide I (4.71\%), 14-hydroxy-9-epi- $(E)$-caryophyllene $(4.62 \%)$ and $2 \alpha$-hydroxy-amorpha-4,7(11)-diene $\quad(4.4 \%)$.

Table 3 Chemical composition of B. alpinum (EO).

\begin{tabular}{|l|c|c|c|}
\hline \multicolumn{1}{|c|}{ Compound } & RI & $\%$ & $\begin{array}{c}\text { Retention } \\
\text { time (min) }\end{array}$ \\
\hline geraniol & 1255 & 0.74 & 18.07 \\
\hline$\beta$-elemene & 1375 & 0.9 & 22.7 \\
\hline$\beta$-caryophyllene & 1417 & 1.96 & 23.8 \\
\hline$\alpha$-humulene & 1452 & 0.35 & 24.92 \\
\hline Sesquicineole & 1471 & 0.42 & 25.14 \\
\hline$\gamma$-muurolene & 1477 & 0.65 & 25.55 \\
\hline$\beta$-selinene & 1485 & 0.32 & 26.03 \\
\hline$\gamma$-gurjunene & 1473 & 0.19 & 26.3 \\
\hline$\beta$-bisabolene & 1509 & 0.32 & 26.45 \\
\hline Elemicin & 1554 & 0.41 & 27.75 \\
\hline ledenoxide I & 1560 & 4.71 & 28.24 \\
\hline 1,5 -epoxy salvial-4(14)-ene & 1571 & 1.42 & 28.77 \\
\hline Spathulenol & 1576 & 2.55 & 29.19 \\
\hline caryophyllene oxide & 1581 & 33.84 & 29.47 \\
\hline salvia-4(14)-en-1-one & 1594 & 3.45 & 29.72 \\
\hline humulene epoxide (II) & 1608 & 8.37 & 30.26 \\
\hline caryophylla-4(12),8(13)-dien-5 $\alpha$-ol & 1639 & 1.12 & 31.16 \\
\hline allo-aromadendrene epoxide & 1639 & 2.62 & 31.34 \\
\hline 14-hydroxy-9-epi-(E)-caryophyllene & 1668 & 4.62 & 32.28 \\
\hline$\alpha$-bisabolol & 1683 & 3.31 & 32.58 \\
\hline $2 \alpha$-hydroxy-amorpha-4,7(11)-diene & 1775 & 4.4 & 32.82 \\
\hline palmitic acid & 1984 & 2.01 & 41.38 \\
\hline n-tricosane & 2300 & 2.24 & 51.3 \\
\hline n-pentacosane & 2500 & 6.41 & 51.45 \\
\hline & & & \\
\hline
\end{tabular}

Thus, terpens and terpens alcohols such as spathulenol, humulene, humulene epoxide I, salvial-4(14)-en1-one and caryophyllene oxide are quantitatively abundant in the two species. The essential chemical groups represented in both EOs are represented in figure $\mathbf{1}$.
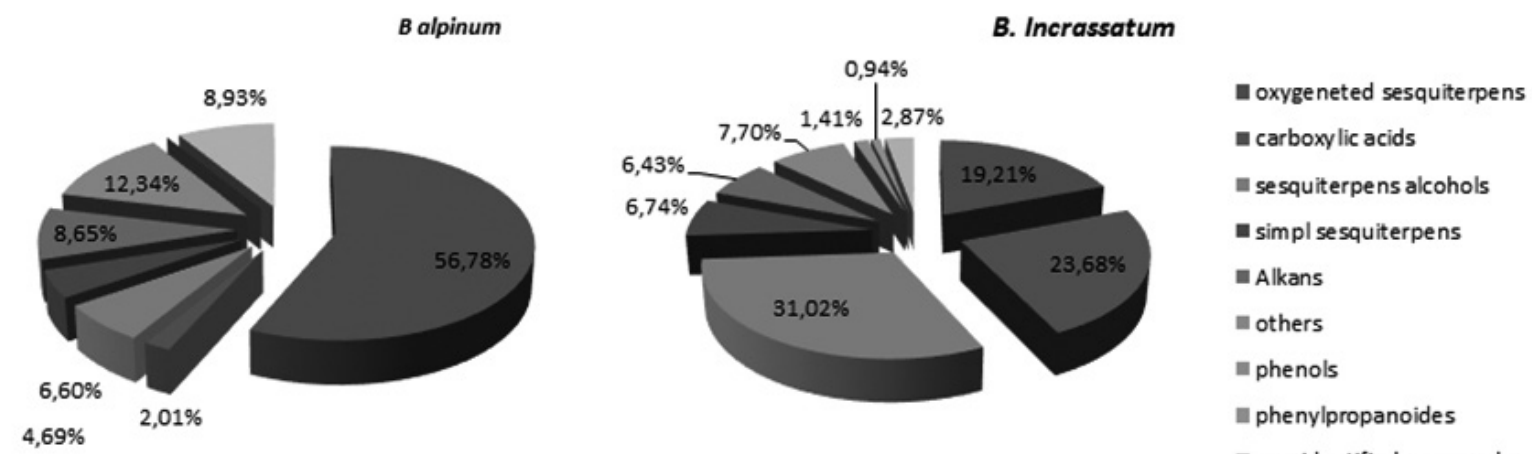

non identified componds

Fig. 1 Yields of chemical groups of components present in EOs 
Interestingly, there were significant differences between the yields and the composition of the two EOs, although they belong to the same genus. These properties in EOs from one species are dependent on several factors; growth location, soil, climate (seasonal variations) ${ }^{24}$, vegetation period, and sunlight ${ }^{25}$. Drying and improper storage can reduce the amount of EO in plants ${ }^{26}$. Many researchers have determined that the maximum oil content is obtained when all the flowers have reached full maturity, because the cups contain the largest number of secretory glands per unit area ${ }^{27}$. To obtain an EO with a constant composition, it must be extracted under the same conditions from the same organ of the plant which was growing on the same soil under the same climate and was harvested in the same season ${ }^{28}$. Also, the composition and the yield of EO can be attributed to the method of extraction ${ }^{29}$.

3.2. Methanolic extracts

Me EXTs were obtained with yields of $1.82 \%$ and $0.89 \%$ for $B$. incrassatum and B. alpinum respectively.

3.3. Total phenolic content (TPC)

TPC expressed in terms of GA and yield (\%) of EXT was found to be $268.2 \mu \mathrm{g} \mathrm{EQ} / \mathrm{mg}(\mathrm{w} / \mathrm{w})$ for B. alpinum EXT and $236.6 \mu \mathrm{g} \mathrm{EQ} / \mathrm{mg}(\mathrm{w} / \mathrm{w})$ for $B$. incrassatum EXT. TPC was calculated using the following linear equation based on the calibration curve of Gallic acid;

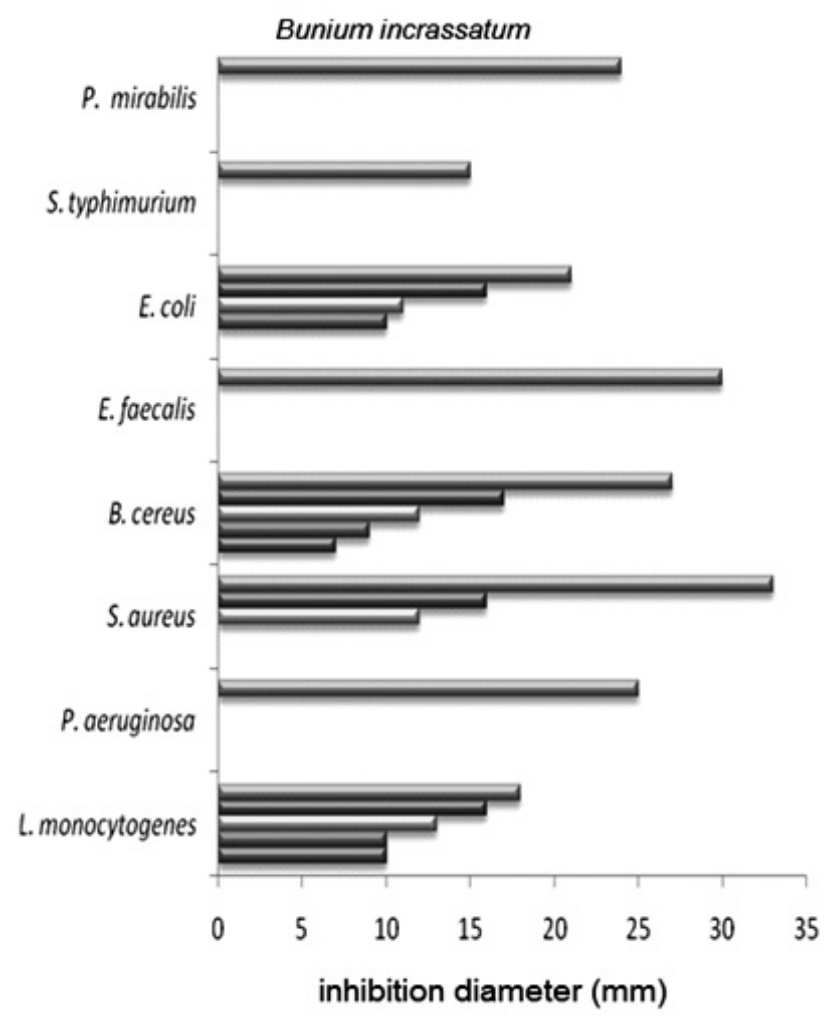

$\mathbf{y}=0.005 x-0.06, R^{2}=0.99$, were $y$ is the absorbance and $x$ is the amount of Gallic acid in $\mu \mathrm{g}$. It is necessary to estimate the TPC in the Me EXTs, because, they were thought to be responsible of different biological activities 30 .

\subsection{Antibacterial activity}

It was reported that herbs and spices containing essential oils (EOs) in the range of $0.05-0.1 \%$ have demonstrated potential activity against bacteriae, such as Salmonella typhimurium, Escherichia coli, Listeria monocytogenes, Bacillus cereus and Staphylococcus aureus, in food systems ${ }^{31}$.

It is clearly seen in figure 2 , that the antibacterial potential is inversely proportional with the dilution of the EOs, and it is well noted that Gentamicin $\left(\mathrm{T}^{+}\right)$inhibited the growth of all bacteria tested by forming halos varied from 7 $\mathrm{mm}$ against $B$. cereus to $33 \mathrm{~mm}$ against $S$. aureus.

EOs of $B$. incrassatum and B. alpinum showed wide array of antibacterial activity. The application of $B$. incrassatum $\mathrm{EO}$ on most bacteria at $10 \%, 20 \%$ and $50 \%$ dilution demonstrated a total resistance. But, concentrations of 100 $\%$ gave remarkable inhibition zone diameters with 15 to $20 \mathrm{~mm}$. However, $B$. alpinum EO presented a good activity against most of bacteria tested, mostly, when using dilution of $50 \%$ and $100 \% \mathrm{EO}$.

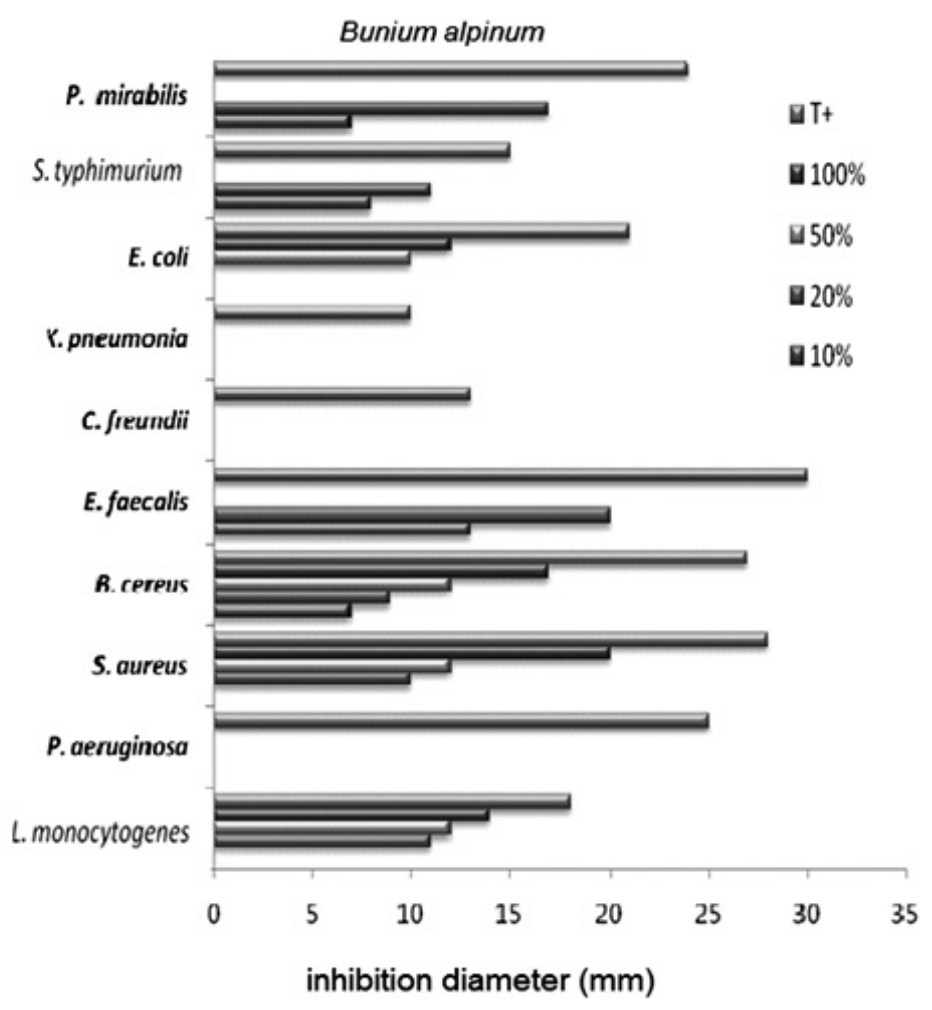

$\mathrm{T}+$ : Gentamicine (10 ug/disc). (100, 50, 20 and 10) \%: Percentages of dilution of EOs in DMSO (v/v)

Fig. 2 Antibacterial activity of the two EOs

The bioactive molecules thought to be responsible for antibacterial activity are terpens and sesquiterpens ${ }^{32}$ which have been obtained in large amounts in B. incrassatum and B. alpinum EOs (more than $50 \%$ in their chemical composition). The antibacterial activity is also attributed to the presence of fatty acids in the composition ${ }^{33,34}$, and the chemical analysis of $B$. incrassatum EO shows the presence of palmitic acid with $18.39 \%$.

The mode of the antibacterial action may be due to surface interaction of these active molecules with the bacterial cell wall and membrane leading to their alteration ${ }^{1}$. Plasmic membrane perturbation, rupture induced by ionic forces and coagulation of cytoplasmic matters are some of the other mechanisms involved in the EOs antibacterial activities ${ }^{35}$.

\subsection{Anti-oxidant activity using DPPH}

Reduction of DPPH radical (blue), which accepts an electron of hydrogen radical to become a stable molecule (yellow), was estimated by the decrease in its absorbance at $517 \mathrm{~nm}$ by antioxidants. The antioxidant capacity is more potential when $\mathrm{IC}_{50}$ is smaller ${ }^{36,37}$.

Figures 3 and $\mathbf{4}$ show the scavenging effect of EOs, Me EXTs and standard antioxidants (BHT, BHA, tocopherol, rutine and quercitine). 

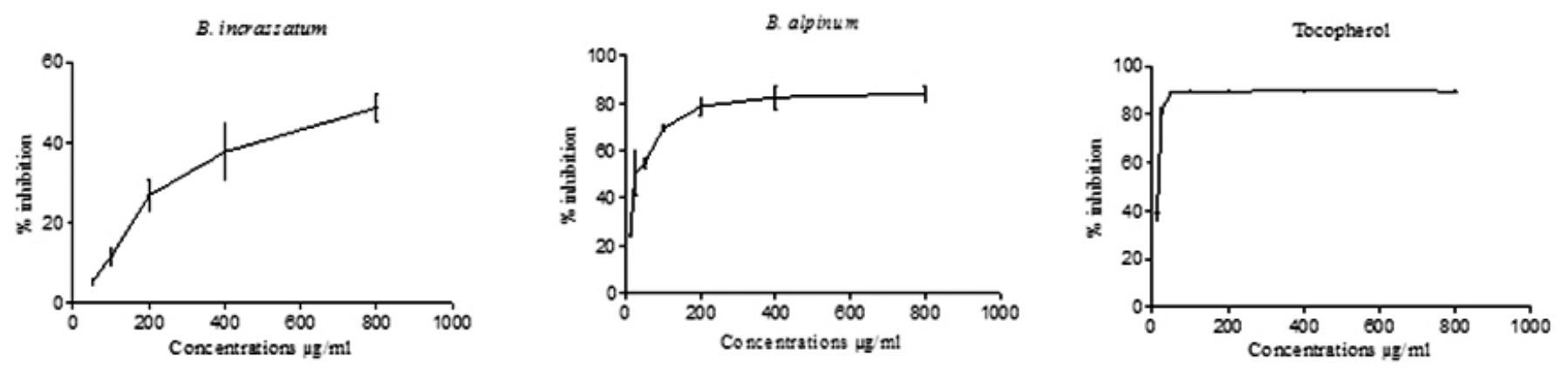

BHA

BHT
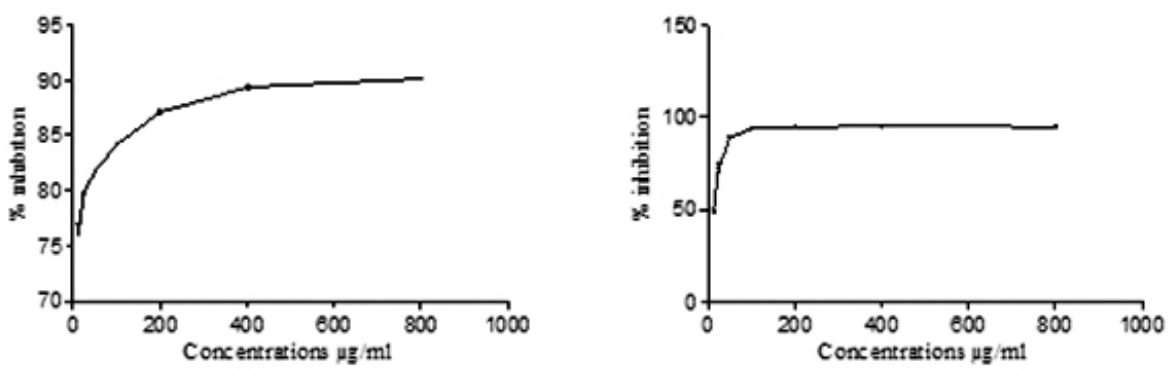

Fig. 3 Scavenger effect of EOs, Tocopherol, BHA and BHT
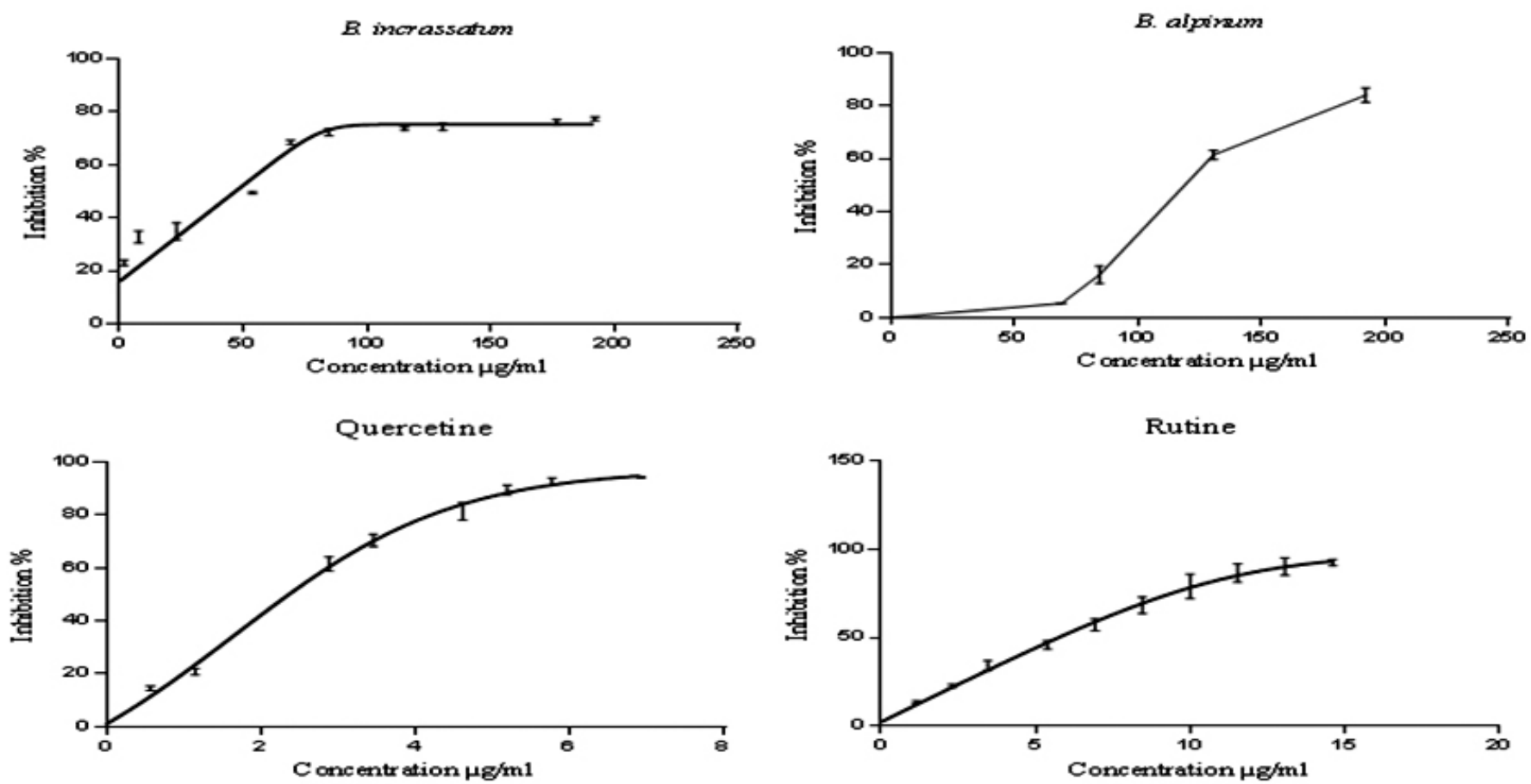

Fig. 4 Scavenger effect of Me EXTs, Quercetine and rutine

Methanolic extracts exhibited the highest scavenging of the DPPH radical, they showed significant results compared to the standards. However, EOs gave the lowest values, meaning not at a level comparable with the standards. $\mathrm{IC}_{50}$ values are presented in table 4 . 
Table 4. $\mathrm{IC}_{50}$ values for EOs and Me EXTs

\begin{tabular}{|l|c|c|c|}
\hline Samples & $I C_{50}(\mu \mathrm{g} / \mathrm{ml}) \pm S D$ & Standards & $I C_{50}(\mu \mathrm{g} / \mathrm{ml}) \pm S D$ \\
\hline B. incrassatum (EO) & $38.52 \pm 2.40$ & BHT & $12.99 \pm 0.41$ \\
\hline B. alpinum (EO) & $>800$ & BHA & $6.14 \pm 0.43$ \\
\hline B. alpinum (Met EXT) & $21.85 \pm 1.32$ & Tocopherol & $13.02 \pm 5.17$ \\
\hline B. incrassatum (Met EXT) & $55.77 \pm 3.25$ & Quercitine & $2.63 \pm 1.26$ \\
\hline & & Rutine & $5.94 \pm 2.00$ \\
\hline
\end{tabular}

Many studies on the anti-oxidant activity of a wide variety of EOs showed that this activity is related to the chemical composition. However the presence of some molecules (even in minority) such as; geraniol, bisabolol (B. alpinum contains $4.05 \%$ ), carvacrol and thymol (B. incrassatum contains $1.41 \%$ ) were found to attribute a high degree of anti-oxidant property by synergy against free radicals ${ }^{38,39}$ and they were found to be as strong reductors of DPPH and inhibitors of the lipidic peroxidation. It was proved that, the anti-oxidant effect is due to the presence of hydroxyl groups in the chemical structure such as quercitine and carnosol which are well known to be good free radical scavengers ${ }^{40-42}$.

\subsection{In vitro Anti-inflammatory activity}

There are certain problems in using animals in experimental pharmacological research, such as ethical issues and the lack of rationale for their use when other suitable methods are available or could be investigated ${ }^{43}$.

The reason for choosing the albumin is that albumin is the most abundant protein in the blood and its concentration drop in cases of inflammation (denaturation) ${ }^{44,45}$, also, albumin acts as primary antioxidant in these cases 46,47 .

The present findings exhibited a concentration dependent inhibition of protein (albumin) denaturation. Also, it is noted that among all samples, at the concentration of $800 \mu \mathrm{g} / \mathrm{Ml}$, showed a significant anti-inflammatory activity and more than $70 \%$ protection of HRBC. Results were compared with standard (Diclofenac Sodium) which showed $\approx 88 \%$ protection. These results are presented in figure 5. Denaturation inhibitory values were calculated and found to be $49.74 \pm 0.90 \mathrm{mg} / \mathrm{ml}$ for $B$. incrassatum EXT; $49.66 \pm 0.94$ for $B$. alpinum EXT. and $49.98 \pm 0.45 \mathrm{mg} / \mathrm{ml}$ for DS.

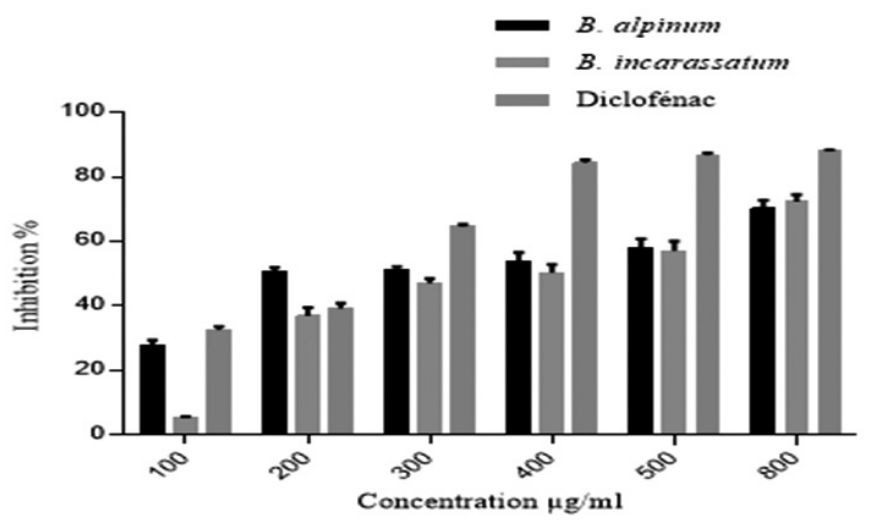

Fig. 5 Protein denaturation inhibitory of B. alpinum and B. incrassatum Me EXTs compared to Diclofenac Sodium.

It was reported that, the presence of secondary plant metabolites such as alkaloids, flavonoids, glycosides, tannins, steroids and sesquiterpens in the composition of the Me EXTs can be responsible for a significant antiinflammatory response $21,44,48$.

\subsection{Anti-hemolytic activity}

The inhibition of hypotonicity induced HRBC membrane lysis or stabilization of HRBC membrane was taken as a measure of the antiinflammatory activity. Me EXTs are effective in inhibiting the heat induced hemolysis of HRBC at different concentrations $(50-2000 \mu \mathrm{g} / \mathrm{ml})$ as shown in figure 6. Results showed the maximum inhibition $\approx 90 \%$ for both extracts at $2000 \mu \mathrm{g} / \mathrm{Ml}$. The inhibition of membrane hemoslysis (membrane stabilization/ protection) increased proportionally with the increase of concentration. Hence, anti-inflammatory activity of the extracts was concentration dependent.

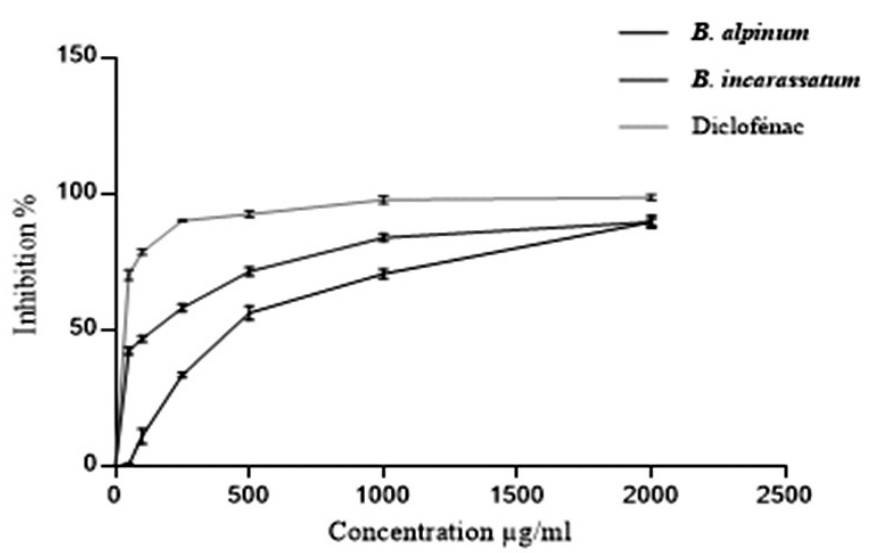

Fig. 6 Effect of B. alpinum, B. incrassatum EXTs and diclofenac sodium on membrane protection.

It has been found that certain chemicals or antioxidants, having ability to generate radicals, attack the erythrocyte membrane, inducing the chain oxidations of lipids and proteins and eventually causing membrane damage leading to hemolysis (during inflammatory process) ${ }^{46}$. Therefore, when HRBC were treated with Me EXTs; a marked reduction in hemolysis and potential anti-inflammatory phenomena were induced. That could be due to their antioxidant potential and free radical scavenging activity ${ }^{50-52}$.

\section{CONCLUSION}

Our results suggested that EOs and Met EXTs of the selected plants can be exploited as effective antibacterial, antioxidant, anti-inflammatory agents. These findings provide scientific basis to justify their traditional use. But, further studies on their cytotoxicity and in vivo applications, must be done for rounding off the evaluation of the potential therapeutic of these plants.

\section{ACKNEWLEDGMENTS}

The profound acknowledgments are to Professor Peyman Selihi from university of Shahid Beheshti of Tehran for helping in chemical analysis.

\section{REFERENCES}

1.- S. Burt. Int J Food Microbiol 94, 223, (2004).

2.- G.V .Degtjareva, E.V. kljuykov, T.H. Samigullin, C.M. Valiejo-Roman, M.G. Pimenov. J Linn Soc Bot 160,149, (2009).

3.- J.V. Shner, T.V. Alexeeva, M.G. Pimenov, W. B.E. Van. S Afr J Bot 626, $6,(2010)$.

4.- A. Bousetla, M. Kurkcuoglu, B. Konuklugil, K.H.C. Baser, S. Rhouati. Chem Nat 50, 753, (2014).

5.- G. Fenu, E. Mattana, A. Congiu, G .Bacchetta. Candollea 65 (2), 347, (2010).

6.- U.R. Rehman Jamil, M .Ahmad, M.A. Saeed, M. Younas, J. Chem Soc Pak 13 (1), 57, (1991).

7.- M. Meshkatalsadat, R. Badri, S. Zarei, Int J Pharm Tech Res 1 (2), 129, 
(2009).

8.- M. Azimzadeh, R. Amiri, M. H. Assareh, M.R. Bihamta, M. Forootan. $J$ Med Plants Res 6 (7), 1119, (2012).

9.- R.K. Thappa, S .Gosh, S.G. Agarwal. Food Chem 41, 129, (1991).

10.- F. F. Charifari, N. Yassa, V. Mozaffarian. Pak J Pharm Sci 23(3), 300, (2010).

11.- G. Appendino, O.H. Cetin, P .Lusso, M .Ciseros. Phytochem 30 (10), 3467, (1991).

12.- U. Cakilcioglua, S. Khatunb, I .Turkogluc, S. Hayta. J Ethnopharmacol 137, 469, (2011).

13.- Leonard A, Lee T and Clyde L. 69 annual meeting of the association of official agricultural chemists. Oct 10-12. Washington (1955).

14.- H. Laouer, M. El Kolli, S, Prado, N. Baldovini. Phytother Res 23 (12), 1726, (2009).

15.- S. Athamena, I. Chalghem, A. Kassah-Laouar, S. Laroui, S. Khebri, Lebanese Science Journal 11,1, (2010).

16.- H. Li, K.W. Cheng, C.C .Wong, K.W. Fan, F. Chen, Y. Jiang. Food Chem 102, 771, (2007).

17.- A.W. Bauer, W.M. Kirby, J.C. Sherris, M.Turck. Am J Clin Pathol 45, 493, (1966).

18.- G .Singh, P. Marimuthu, C.S. De Heluani, C. A. N. Catalan. J. Agric. Food Chem 54,174, (2006).

19.- M. Barkat, I. Laib. Revue de génie industriel. 6, 46, (2011).

20.- P. Padmanabhan, S. N. Jangle. Int J app Basic Med Sci 2(1), 109, (2012).

21.- F. Alhakmani, S. Kumar, S. A. Khan. Asian Pac J Trop Biomed 3(8), 623, (2013).

22.- W. M. Nishanthi, M. Vijey Aanandhi, K. Azhagesh Raj, B. Vijayakumar. Journal of Pharmacological Screening Methods 2, 88, (2012).

23.- O. T. Kolawole, M. O. Akiibinu, A. A. Ayankunle, E. O. Awe. Br J Med Med Res 3 (2), 216, (2013).

24.- R. Omidbaigi, A. J. Arvin. J Essent Oil Bear Pl 12, 34, (2009).

25.- B. H. Naghdi, D. Yazdani, S. Mohammad Ali, F. Nazari. Ind Crops Prod 19, 231, (2004).

26.- F. Sandberg, D. Corrigan. Natural Remedies; Their Origins and Uses. Taylor \& Francis e-Library. (2004).

27.- A. Rahman, M.I. Choudhary, S. Hayat, A.M. Khan, A. Ahmad, S. Malik. Phytochem. 52, 495, (1999).

28.- F. Bakkali, S. Averbeck, D. Averbeck, M. Idaomar. Food Chem Toxicol .46, 446, (2008).

29.- S. Khosravinia, S. M.Ziaratnia, A. Bagheri, G Rajabzadeh, S. H. Marashi. Not Sci Biol. 4, 49, (2012).

30.- C.C. Seema, S.V. Sharan, R.B. Srinivasa, V. Meena. Rasayan J Chem. 4, 457, (2011).

31.- M.M. Tajkarimi, S.A. Ibrahim, D.O. Cliver. J Sci Food Agr 76(2), 270, (2010).

33.- S.G.Griffin, S.G. Wyllie, J.L. Markham, D.N. Leach. Flavour Fragr J. 14, 322, (1999).

34.- H. Baydar, O. Sagdic Ozkan, T. Gand Karadogan. Food Control. 15, 169, (2004).

35.- M. El kolli, H. Laouer, H. El Kolli, S. Akkal, F. Sahli. Asian Pac J Trop Biomed. 6(1), 8, (2016).

36.- B. Tepe, D. Daferera, A. Sokmen, M. Sokmen, M. Polissiou. Food Chem. 90, 333, (2005).

37.- N. Benhammou, F. A. Bekkara, T. K. Panovska. C R Chimie. 12,59, (2009).

38.- F. Lu, L.Y. Foo. Food Chem.75, 197, (2001).

39.- T. Nalina, Z. Rahim. Chem Biochem. 3, 10, (2007).

40.- Bruneton J. Pharmacognosie et Phytochimie des Plantes Médicinales. Tec \& Doc. Paris. (1999).

41.- Multon J. L. Additifs et Auxiliaires de Fabrication dans les Industries Agroalimentaires, Lavoisier, Paris. (2002).

42.- T. Kulisic, A. Radonic, V. Katalinic, M. Milos. Food Chem. 85, 633, (2004).

43.- S .Chandra, P .Chatterjee, P. Dey, S. Bhattacharya. Asian Pac J Trop Biomed. S178, (2012).

44.- S .Sachin, S. Archana, R. Juvekar, M. N. Gambhire. Int J Pharm Pharm Sci 2 (1), 146, (2010).

45.- J. Pastre, N. Priymenko N. Revue Med Vet 158 (4), 180, (2007).

46.- J. Neuzil, R. Stocker. J Biol Chem 269 (24), 16712, (1994).

47.- D. W. Appleton, B. Sarkar B. J Biol Chem 246 (16), 5040, (1971).

48.- M. Bourkhis, M .Hnach, J. Paolin, J. Costa, A. Farah, B. Satrani. Bulletin de la Société Royale des Sciences de Liège 79, 141, (2010).

49.- D. Chakraborty, B. Shah. Int J Pharm Pharm Sci 3 (3), 192, (2011).
50.- F. Dai, Q. Miao, B. Zhou, L. Yang, Z.L. Liu. Life Sci 78, 2488, (2006).

51.- M. Blasa, M. Candiracci, A. Accorsi, M. P. Piacentini, E. Piatti. Food Chem 104 (4), 1635, (2007).

52.- J. Tabart, C. Kevers, J. Pincemail, J. O. Defraigne, J. Dommesa. Food Chem 113, 1226, (2009). 